\title{
Research on the Selection of Vertical and Horizontal Type of the Foreign Direct Investment of Multinational Enterprise and Its Influencing Factors
}

\author{
Zeng Xiaolong, Wang Shuhui \\ Economics School, Tianjin University of Finance and Economics, Tianjin, China \\ Email address: \\ zengx10914@sina.com (Zeng Xiaolong),13752005966@163.com(Wang Shuhui)
}

\section{To cite this article:}

Zeng Xiaolong, Wang Shuhui. Research on the Selection of Vertical and Horizontal Type of the Foreign Direct Investment of Multinational Enterprise and Its Influencing Factors. Journal of Investment and Management. Vol. 5, No. 5, 2016, pp. 39-44. doi: $10.11648 /$ j.jim.20160505.11

Received: August 1, 2016; Accepted: August 9, 2016; Published: September 10, 2016

\begin{abstract}
Since the 1970s, international trade and investment patterns have occurred great changes, also the production organization of international enterprises had undergone profound changes. Intra-industry trade gradually replace the inter-industry trade, has become the main form of international trade. After 1980s, the multinational enterprises got unprecedented development. All the data are from the U.S. Bureau of Economic Analysis and the World Bank.
\end{abstract}

Keywords: Foreign Direct Investment, Horizontal FDI, Vertical FDI, Panel Data, Influencing Factors

\section{Preface}

According to the definition of Multinational Enterprise by western economists, it is an "international corporation which set up branches in foreign countries and engage in the production, sales and other business activities through the way of FDI". Foreign direct investment is a prerequisite for the development and emergence of multinational enterprise. According to the definition of the International Monetary Fund, international direct investment refers to a "investment behavior that a country's investors use the capital for the production and operation in other countries and master certain rights of management control; it also can be described as an investment that the resident entities (foreign direct investors or parent company) establish a long-term relationship with a corporation in another country, foreign direct investment enterprises or subsidiary, enjoy a lasting interest and control of the enterprise".

Zhang jianhong (2004) pointed out that the characteristics of the multinational enterprise depends largely on the characteristics of the home country and the link between host country and home country, so the relationship between the host country and home country and their respective characteristics can explain the types and motivation of international direct investment between the two countries.
In accordance with the different motives, the 1998 World Investment Report, announced by United Nations Conference on Trade and Development (UNCTAD), pointed out: FDI can be divided into market-seeking, resource or asset seeking and efficiency-seeking FDI. FDI can also be divided into vertical FDI (export-oriented) and horizontal FDI (market-oriented) (Markusen, 1995). Vertical FDI refers to the one that distributes its production processes in different countries according to the prices of production factors, mainly in order to make full use of the factor endowments differences between countries, also known as resource-oriented FDI. Products are mainly for export for the host country. Horizontal FDI refers to Copy of the final product lines in the host country in order to close to the local market, also known as the market-seeking FDI. The products are sold in the host country. The essential difference between horizontal and vertical multinationals is that multinational enterprises product primarily to satisfy the needs of the host country or the needs of home country or other countries.

Based on multinational enterprises, the author studies of the decision making of its transnational direct investment and focuses on the decisions of the multinational enterprise foreign direct investment and its influencing factors. There is a great significance of this research. Firstly, it is helpful for the multinational companies to grasp and create investment opportunities, to make a timely, correct and scientific 
investment decisions, to obtain the competitive advantage of the industry and achieve the goal of benefits maximization. Secondly, it is beneficial to the host country to understand and master the motive and intention of the foreign direct investment of a multinational company and continuously improve the investment environment, can also continue to improve the laws and regulations related to the introduction of investment, to carry on the effective monitoring while enjoying the benefits bring by the investment of multinational companies. Finally, it is conducive to home country to achieve the economic and non-economic countries motivation and the will through the form of foreign direct investment of multinational corporations, so as to strive for the competitive advantage of nations and achieve the maximization of national interests.

\section{Literature Review}

Foreign direct investment of multinational corporations has become the important driving force of the development of economic and trade (Wang, 2009). Policymakers in both developed and developing countries think that FDI can significantly improve the economic structure of a country, promote technological progress, economic growth and employment increase (Brooks et al., 2010). In view of the importance of multinational enterprise FDI to a country's economic development, so there are a lot of related research about multinational FDI (Assuncao, 2011). Over the past few decades, the rapid development of international trade and FDI has a growing effect on economic development (Mohamed and Sidiropoulos, 2010), which has inspired a wide range of researching for multinational enterprise and its FDI (Faeth, 2006).

Vertical direct investment theory (Helpman, 1984) think that the motivation of the foreign direct investment is the difference of factor endowments and horizontal direct investment theory (Markusen, 1984) think the motivation is the economics of scale and trade cost. These two theories are incompatible with each other, but tend to exist in reality at the same time. It is difficult to distinguish between them. To solve this problem, while eliminating the original hypothesis defects existing in the two theories, Markusen (1996) put the horizontal and vertical investment at the same time into one model called Knowledge Capital Model, referred to as KK model. The conclusion is that when the size of economy and the resources endowment are similar and the transportation cost of medium or large, the horizontal direct investment will be dominant. There are differences between the two countries in factor endowments, especially when skilled labor abundant country's economy is relatively small, the vertical investment will account for a dominant position.

The attention to study the differences between horizontal and vertical FDI are rare after that. Venables (1999) studied the impact of separation of different stages of production on the activities of multinational enterprise. It is considered that the development of the vertical or horizontal multinationals is caused by the separation of different production stages, the motivation of the foreign investment of the multinationals depends on the intensity factors of the upstream and downstream production. Markusen and Maskus (2001) pointed out that the trade costs of exporting from home country to the host country will promote horizontal FDI. Hanson et al. (2001) believe that both vertical and horizontal FDI are important, but it is difficult to clearly distinguish the motivation between them from the data. Yeaple (2003) established of a static general equilibrium model. The results of the empirical analysis shows that lower transportation costs and the relatively low wages of host country will lead to vertical multinational companies, high transport costs and the relative higher wages of host country will promote the horizontal multinational companies, medium to higher transportation costs and the high wages of the host country promote complex integrated investment of multinational company. Aizenman and Miron (2004) pay attention to the different impacts of supply uncertainty on horizontal and vertical FDI. Yokota Kazuhiko (2007) concluded that the horizontal and vertical foreign direct investment in the United States has different motivations, each of which depends on the size of the host country market and factor endowments. Buckley et al. (2007) studied the motivation of China's foreign direct investment, and found that the size of the market, resource endowment, geographical proximity and cultural tightness of the host country is proportional to the foreign direct investment.

\section{Model Construction and Quantitative Analysis}

\subsection{Selection of Samples and Data}

Because the foreign direct investment in the United States occupies an extremely important position in the world's total foreign direct investment, the United States is more representative. Therefore, this paper takes multinational enterprise as the object of study, and thus promote to the general situation, and can clear the strategic selection of foreign direct investment of all the multinational enterprises.

In this paper, we select the relevant data from 2000 to 2012 of majority-owned foreign affiliates which are branches of multinational enterprises of the United States to establish a panel data ${ }^{1}$ model and carry on empirical test. The data comes from the BEA and the World Bank.

\subsection{Construction of Measurement Model}

In the trade literature, the popular view is that foreign direct investment is basically horizontal, that is to say, the companies of United States copy the production process of domestic to go abroad, and products in abroad is mainly used to meet the demand of local market of host country. This type of foreign direct investment is not to seek the cheap cost of factors of production but in order to avoid the trade barriers and transportation costs. However, as is shown in Table 1, U.S.

\footnotetext{
1 Panel data is a combination of cross-section data and time-series data.
} 
multinational companies carry out both vertical foreign direct investment and horizontal foreign direct investment.

Table 1. Percentage of subsidiaries of multinational enterprises of the United States (\%).

\begin{tabular}{lllll}
\hline & \multirow{2}{*}{ Host country } & Foreign country & \\
\cline { 3 - 5 } & & Total & $\begin{array}{l}\text { To United } \\
\text { States }\end{array}$ & $\begin{array}{l}\text { To other } \\
\text { countries }\end{array}$ \\
\hline 2012 & 58.49 & 41.51 & 9.92 & 31.59 \\
2011 & 58.60 & 41.40 & 10.45 & 30.95 \\
2010 & 59.87 & 40.13 & 10.65 & 29.49 \\
2009 & 60.47 & 39.53 & 10.67 & 28.86 \\
2004 & 61.92 & 38.08 & 10.70 & 27.38 \\
2003 & 63.96 & 36.04 & 10.22 & 25.82 \\
2002 & 64.50 & 35.50 & 10.91 & 24.59 \\
2001 & 64.43 & 35.57 & 10.78 & 24.79 \\
2000 & 65.79 & 34.21 & 11.48 & 22.73 \\
\hline
\end{tabular}

Source: U.S. Bureau of Economic Analysis

This paper is based on Knowledge Capital Model ${ }^{2}$ used by Carr, Markusen and Maskus (CMM) and emphasis on the decisive effect of trade costs, national economy and the labor endowment on foreign direct investment of multinational companies. Unlike the CMM model, this paper makes the following changes. Firstly, it eliminates the "Investment Cost Host" because of its small interannual variability. Secondly, it excludes the interaction item of "Trade Cost Host" and the "Skill Difference Square", due to the interpretation ability is not strong. Finally, this paper removes the items of "Trade Cost Host" and "Trade Cost Parent", because the variable of distance reflects the cost of trade and investment in a certain extent. In addition, the data of u.s. multinational enterprises is divided into three parts: sales in the host countries, exports to the United States and exports to the third country. It is considered that the activity of exporting to the United States is much closer to the vertical FDI, the other two are more close to the horizontal FDI. Finally, the model of this paper is as follows:

$$
\begin{aligned}
\text { Real Sales }_{\mathrm{jt}} & =\beta_{0}+\beta_{1}(\text { GDP SUM })_{\mathrm{jt}} \\
& +\beta_{2}(\text { GDP Difference Squared })_{\mathrm{jt}} \\
& +\beta_{3}(\text { Skill Difference })_{\mathrm{jt}} \\
& +\beta_{4}\left([\text { GDP Difference }]^{*}[\text { Skill Difference }]\right)_{\mathrm{jt}} \\
& +\beta_{5}(\text { Dis tan ce })_{\mathrm{j}}+\mu_{\mathrm{j} \mathrm{t}}
\end{aligned}
$$

Where,

Real Sales: Sales of affiliates in the host country

The dependent variable of horizontal FDI should be the sales of the host country's markets while the vertical FDI should be the export amount of the affiliates.

GDP SUM: The sum of GDP of home country and host country

GDP Difference Squared: The square of the difference between the home country and host country's GDP

Skill Difference: The skilled labor factor endowment

2 Real Salesij $=\beta_{0}+\beta_{1} *($ GDP SUM $)+\beta_{2} *$ (GDP Difference Squared $)+\beta_{3} *$ (Skill Difference $)+\beta_{4} *([$ GDP Difference $] *[$ Skill Difference $])+\beta_{5} *$ (Investment Cost Host $)+\beta_{6} *$ (Trade Cost Host $)+\beta_{7} *([$ Trade Cost Host $] *$ [ Skill Difference Square $\left.]\right)$ $+\beta_{8} *($ Trade Cost Parent $)+\beta_{9} *$ (Distance) difference between home country and host country

Distance: The distance between home country and host country

\subsection{Variable Analysis and Symbolic Prediction}

GDP SUM shows the sum of GDP between home country and host country and the variable value is greater, the greater the size of the markets between two countries. According to the knowledge capital model, the symbol should be positive.

The variable of GDP Difference Squared reflects the difference of the size of markets between home country and host country. Prediction of the symbol should be negative.

This paper uses the rate of the higher education enrollment to measure the variable of "Skill Difference". The variable reflects the differences of the abundance of skilled labor between the two countries. The symbol for the prediction of the variable is positive.

The interactive item [GDP Difference]*[Skill Difference] reflects that there will be more vertical FDI when the size of home country is relatively small and the skilled labor is abundant. The symbol is expected to be negative.

The prediction of distance symbol is negative.

\subsection{Results and Analysis}

First, there is an overall analysis of the sales of affiliates of multinationals, the regression results are shown in table 2 .

Table 2. The regression results of sales situation of affiliates.

\begin{tabular}{lll|l}
\hline & $\begin{array}{l}\text { Symbol } \\
\text { prediction }\end{array}$ & $\begin{array}{l}\text { Estimate and } \\
\text { standard error }\end{array}$ & 'P' value \\
\hline GDP SUM & + & $\begin{array}{l}1.2546^{* * *} \\
(5.5038)\end{array}$ & $5.579 \mathrm{e}-08$ \\
& & $\begin{array}{l}-5.5122^{* * *} \\
(-4.2671)\end{array}$ & $2.312 \mathrm{e}-05$ \\
GDP Difference Squared & - & $\begin{array}{l}-4.2934 \\
(-1.1199)\end{array}$ & 0.26322 \\
Skill Difference & + & $\begin{array}{l}9.3791 \\
(0.2769)\end{array}$ & 0.78194 \\
[GDP Difference] & - & $\begin{array}{l}-2.2319 * \\
(-2.0358)\end{array}$ & 0.04222 \\
\hline * [Skill Difference] & - & & \\
\hline Distance & - & &
\end{tabular}

Note: Signif. codes: $0{ }^{\prime * * * '} 0.001^{\prime * * \prime} 0.01^{\prime * \prime} 0.05$ '.' $0.1^{\prime}$ '1

The coefficient of GDP SUM is positive, which explained that the bigger GDP SUM is, the more likely they will promote direct investment for the host country. It is consistent with the actual situation, the larger the bilateral economic size, the greater the level of economic development and the markets demand of the two countries. This is bound to promote investment.

GDP difference squared measures of the differences of economies size between two countries, the symbol is same as the expected. In the knowledge capital model, the bigger the difference of economic size between them, the stronger the inhibitory effects on the home country's investment. There is an inverted $U$ shaped relationship between overseas sales and national size differences, when the difference is zero, the investment (branch Sales) maximum.

The coefficient of Difference Skill is negative, which shows 
that U.S. foreign direct investment as a whole is dominated by horizontal one.

The interaction item [GDP Difference]*[Skill Difference] reflects that vertical direct investment is more when home country is relatively small and skilled labor is more abundant. The symbol is different from anticipated before. Possible reason is that the knowledge capital model think that when the home country is relatively small and skilled labor abundant, vertical production activities of multinationals will be more, while the United States as the home country, obviously relative to other countries is a big country. From the point of view of the world, China is a notable example in this situation, which the home country of multinationals is small and abundant in skilled labor while the host country is big and abundant in unskilled labor. As a developing country, China's skilled labor endowment is scarce compared to most of the home country of multinationals. So if the relevant data of China are used to analyze this problem, the coefficient symbol will meet expectation.

To a certain extent, the variable of Distance reflects the trade cost and investment cost and its estimation coefficient is negative, which shows that it has a slight inhibitory effect on foreign investment of the United States.

Next, the regression analysis respectively to the local sales, exports to the United States and exports to the third country will be carried out and the results are shown in Table 3 .

Table 3. Results of measurement and inspection.

\begin{tabular}{|c|c|c|c|c|}
\hline & Symbol prediction & exports to the US & local sales & exports to other countries \\
\hline GDP SUM & + & $\begin{array}{l}2.7779 * * * \\
(11.2145)\end{array}$ & $\begin{array}{l}1.5274 * * * \\
(11.0440)\end{array}$ & $\begin{array}{l}7.0018 * * * \\
(9.5097)\end{array}$ \\
\hline GDP Difference Squared & - & $\begin{array}{l}-1.0406 * * * \\
(-7.7597)\end{array}$ & $\begin{array}{l}-6.8937 * * * \\
(-8.9792)\end{array}$ & $\begin{array}{l}-1.7404 * * * \\
(-4.4137)\end{array}$ \\
\hline Skill Difference & + & $\begin{array}{l}1.2998 * * * \\
(3.6579)\end{array}$ & $\begin{array}{l}5.4867 \\
(0.2524)\end{array}$ & $\begin{array}{l}5.3700 * * * \\
(4.9919)\end{array}$ \\
\hline $\begin{array}{l}\text { [GDP Difference] } \\
*[\text { Skill Difference }]\end{array}$ & - & $\begin{array}{l}-5.1149 \\
(-1.7379)\end{array}$ & $\begin{array}{l}-2.0939 \\
(-1.1539)\end{array}$ & $\begin{array}{l}-3.9419 * * * \\
(-4.4728)\end{array}$ \\
\hline Distance & - & $\begin{array}{l}-9.5932 * * * \\
(-3.8409)\end{array}$ & $\begin{array}{l}-2.2717 \\
(-1.9461)\end{array}$ & $\begin{array}{l}-9.8792 \\
(-1.4138)\end{array}$ \\
\hline
\end{tabular}

Notes:

(1) The number of each cell in the table is the parameter estimation and ' $t$ ' value.

(2) Signif. codes: $0{ }^{\prime * * * 1} 0.001^{\prime * * 1} 0.01^{\prime * 1} 0.05$ '.' $0.1^{\prime}$ '1

According to the above conclusion, the horizontal transnational company's main objective is selling in the markets of host country while vertical multinational enterprises is mainly make full use of the factor endowments differences between different countries and for the host country specific products are for export. AEX, ALS, and
SALES respectively represent the exports, local sales and total sales of the affiliates of the multinational enterprises. When the ratio of AEX and SALES increases, the investment is more vertical, when the ratio of ALS and SALES increases, the investment will be more horizontal. Combining these two indexes to form a new index formed AEX/ALS.

Table 4. Measurement results of different samples.

\begin{tabular}{|c|c|c|c|}
\hline & exports to the US & local sales & exports to other countries \\
\hline D30_GDP SUM & $\begin{array}{l}6.2874 * * * \\
(11.4029)\end{array}$ & $\begin{array}{l}5.5305 * * * \\
(15.2525)\end{array}$ & $\begin{array}{l}1.8601 * * * \\
(7.7926)\end{array}$ \\
\hline D30_GDP Difference Squared & $\begin{array}{l}-2.3890 * * * \\
(-8.0109)\end{array}$ & $\begin{array}{l}-2.6659 * * * \\
(-13.0575)\end{array}$ & $\begin{array}{l}-5.7169 * * * \\
(-4.4906)\end{array}$ \\
\hline D30_Skill Difference & $\begin{array}{l}2.9201 * * * \\
(3.5364)\end{array}$ & $\begin{array}{l}7.0512 \\
(1.0893)\end{array}$ & $\begin{array}{l}1.2023 * * * \\
(3.5324)\end{array}$ \\
\hline D30_[GDP Difference] & $-1.4464 *$ & -5.8887 & $-8.4116^{* *}$ \\
\hline D30_Distance & $\begin{array}{l}-7.1269 * * \\
(-2.8807)\end{array}$ & $\begin{array}{l}-1.7958 \\
(-1.5941)\end{array}$ & $\begin{array}{l}-1.6048 \\
(-1.2433)\end{array}$ \\
\hline D70_GDP SUM & $\begin{array}{l}1.9082 * * * \\
(7.5664)\end{array}$ & $\begin{array}{l}1.0108 * * * \\
(9.3411)\end{array}$ & $\begin{array}{l}4.8621 * * * \\
(10.2241)\end{array}$ \\
\hline D70_GDP Difference Squared & $\begin{array}{l}-6.6029 * * * \\
(-4.8355)\end{array}$ & $\begin{array}{l}-4.6083 * * * \\
(-7.5518)\end{array}$ & $\begin{array}{l}-9.8923 * * * \\
(-3.8971)\end{array}$ \\
\hline D70_Skill Difference & $\begin{array}{l}1.2310 * * * \\
(3.3986)\end{array}$ & $\begin{array}{l}-1.1199 \\
(-0.6310)\end{array}$ & $\begin{array}{l}5.0217 * * * \\
(7.1506)\end{array}$ \\
\hline D70_[GDP Difference] & -4.4495 & -7.8731 & $-3.9840 * * *$ \\
\hline *[Skill Difference] & $(-1.4701)$ & $(-0.5068)$ & $(-6.8916)$ \\
\hline D70_Distance & $\begin{array}{l}-1.1237 * * * \\
(-3.9398)\end{array}$ & $\begin{array}{l}-2.6251 * * * \\
(-3.7547)\end{array}$ & $\begin{array}{l}-8.3678 \\
(-1.4062)\end{array}$ \\
\hline
\end{tabular}

Notes:

(1)The number of each cell in the table is the parameter estimation and ' $t$ ' value.

(2)Signif. codes: $0{ }^{\prime * * *} 0.001^{\prime * * 1} 0.01^{\prime * \prime} 0.055^{\prime}$.' $0.1^{\prime \prime}$ '1

(3)D30: in the top $30 \%$ of the sample, D70: in the bottom $70 \%$ of the sample 
According to the decreasing order of AEX/ALS, the sample will be divided into two parts. The sample with relatively high ratio involves more vertical FDI, another sample contains more horizontal FDI. In order to distinguish between horizontal and vertical FDI, these two samples are estimated respectively and the symbol of Skill Difference will be tested. The results are shown in Table 4.

In the above results, D_30 covers the top 30\%, D_70 covers the remaining $70 \%$. The regression results of the first column on the export of the United States shows that the coefficient of horizontal and vertical FDI is significantly different. In addition, the vertical FDI has a higher value than the horizontal one in the coefficient of Skill Difference, which shows that vertical FDI is more sensitive to factor endowments.

In the second column, judging from the size and significance of the coefficient, horizontal FDI and vertical FDI does not exist obvious difference on the level of local sales, the elasticity of the horizontal FDI is bigger than the elasticity of vertical FDI. The coefficient of Skill Difference is positive in the vertical FDI but it is negative in the horizontal FDI, which indicates that the similarity of factor endowments promotes the local sales under the situation of horizontal FDI and hinders it under the situation of vertical FDI.

The third column shows almost the same trend as the export to the US market. For horizontal FDI, the similarity of factor endowments stimulate the strategy of exports to other markets, but for vertical FDI, there is a obstructive effect on this strategy.

\section{Conclusions}

This paper distinguishes between horizontal and vertical FDI based on the knowledge capital model, the estimated results show that there is a difference between horizontal and vertical FDI. Factor endowments play a key role in the process of dividing the sample into two groups. The analysis results show that the host country will attract horizontal direct investment when the differences of size in home country and the host country's markets is small, on the contrary, will attract vertical foreign direct investment; the host country will attract vertical FDI when differences of skilled labor abundance is large otherwise will attract horizontal FDI. The coefficients of Difference Skill play a pivotal role in differentiating the two types of FDI, the more similar factor endowments are, the more likely it is that horizontal FDI will occur. Therefore, for the model of horizontal foreign direct investment, the expected symbol is negative. In the vertical FDI, the coefficient reflects the relative cost of production factors and is sensitive to the skilled labor abundance in the host country economy. For vertical FDI, the greater the difference in technology endowments, the more likely it is to generate vertical FDI. Therefore, the expected sign is positive for the model of vertical FDI.

Overall, the host country will attract horizontal direct investment when the differences in home country and the host country's market size and skilled labor abundance is small and factor endowments is similar. On the contrary, it will attract vertical type of direct investment.

For China, China's own characteristics determine the vertical type of multinational enterprise is more likely to appear. Foreign direct investment pay more attention to the size of the market compared to labor costs, the convergence of China and other countries in GDP will increase the scale of foreign direct investment of China. When the skilled labor of home country is abundant and skilled labor endowments difference with China is high, there will be more multinationals activities in China. The bigger the absolute value of the GDP difference between these countries (except for the US) and China is, the greater the endowments difference influence on overseas activities. When the home is small, skilled Labor scarce, the improvement of skilled Labor endowments will increase the overseas activities of its multinational company.

\section{References}

[1] Zhang Weifu, Zhai Dongping. Theoretical research on the transformation between international vertical integration and outsourcing: Based on the perspective of negotiation cost under incomplete contract[J]. Nankai Economic Studies, 2010, (6): 86-97.

[2] Xue Mantian, Zhao Shudong. Foreign Direct Investment: Vertical or horizontal [J]. Economic Research Journal, 2007, (12): 93-105.

[3] Zhang Jianhong. Research on the characteristics of the investment country and the intensity of its investment in China [J]. The World Economy, 2004, 1.

[4] Kong Xin, Li Jianxin. Enterprise heterogeneity: Export trade, foreign direct investment and enterprise outsourcing $[\mathrm{N}]$. Journal of Guizhou College of Finance and Economics. 2011 (6).

[5] Li Donghong, Zhou Guoxiang. A discussion on the vertical specialization development of multinational enterprise [J]. Inquiry into Economic Issues, 2003, (1): 82-86.

[6] Jiang Hui. Study on the decision making of foreign direct investment of Multinational Corporation [D]. Wuhan University of Technology, 2004.

[7] Liu Xiaochang, Liu Zhibiao. Study on the vertical specialization development trend of multinational corporation and the competition strategy of enterprise in China [J]. Jianghai Academic Journal, 2001, (4): 32-37.

[8] Liu Jian. U.S. Multinational Corporation's foreign direct investment strategy and its impact on the U.S. trade [D]. University of International Business and Economics, 2002.

[9] Chen Zhi. Research on the foreign direct investment of Multinational Corporation [D]. Wuhan University of Technology, 2002.

[10] Lan Lijuan. Evolution of foreign direct investment in the United States and its implications for China [D]. Dongbei University of Finance and Economics, 2007. 
[11] Mao Jinsong. Internal trade of Multinational Corporation and FDI -- Taking the Multinational Corporation in China as the object of study [D]. Nankai University, 2014.

[12] Xu Shuwei. Analysis of the motivation of China's foreign direct investment based on the knowledge capital model [D]. Shandong University of Finance and Economics, 2013.

[13] Kazuhiko Yokota, Qin Lijing. The horizontal and vertical Multinational Corporation [J]. Journal of Translation from Foreign Literatures of Economics, 2007 (2): 23-41.

[14] Wan Lian. The study of the influence of the changes in RMB real exchange on China's vertical and horizontal FDI [D]. Zhejiang Gongshang University, 2010.

[15] Markusen. The Boundaries of Multinational Enterprises and the Theory of International Trade [J]. Journal of Economic Perspectives, 1995, 9: 169-189.

[16] Brooks, D. H.; Hasan, R.; Lee, J.-W.; Son, H. H.; Zhuang, J. Closing development gaps: Challenges and policy options [R]. ADB Economics Working Paper Series 209, Manila: Asian Development Bank, 2010.

[17] Assuncao, S., Forte, R., \& Teixeira, A. A. Location determinants of FDI (No. 433) [R]. Universidade do Porto, Faculdade de Economia do Porto, 2011.

[18] Mohamed S E, Sidiropoulos M G. Another look at the determinants of foreign direct investment in MENA countries: An empirical investigation [J]. Journal of Economic Development, 2010, 35 (2): 75-95.
[19] Faeth I. Consequences of FDI in Australia-Causal Links Between FDI, Domestic Investment, Economic Growth and Trade [J]. Department of Economics Research Paper, 2006, 977.

[20] Helpman E. A Simple Theory of Trade with Multinational Corporations [J]. Journal of Political Economy, 1984, 92 (3): 451-571.

[21] Markusen J. R. Multinationals, multi-plant economies, and the gains from trade [J]. Journal of International Economics, 1984, 16 (3): 205-226.

[22] Wang M. Manufacturing FDI and economic growth: evidence from Asian economy [J]. Applied Economics, 2009, 41 (8): 991-1002.

[23] Yeaple S R. The complex integration strategies of multinationals and cross country dependencies in the structure of foreign direct investment [J]. Journal of International Economics, 2003, 60 (2): 293-314.

[24] Buckley, P. J., Clegg, L. J., Cross, A. R., Xin, L. et al., The determinants of Chinese outward foreign direct investment [J]. Journal of International Business Studies, 2007, 38 (4): 499-518.

[25] Kazuhiko Yokota, Export-led Growth of Developing Countries and Optimal Trade Policy, Area Studies, 41, 2007, pp. 133-144. 